\title{
Bursting the bubble: Mythical Englishness, Then and Now
}

CHRISTINE BERBERICH, UNIVERSITY OF PORTSMOUTH, UK

\section{Christine.berberich@port.ac.uk}

Abstract: This article assesses the creation of specifically English myths, especially that of the Southern English landscape as the one marker of a quintessential Englishness, in the first three decades of the twentieth century. Taking H.V. Morton's In Search of England as a case study, the article shows that Morton consciously created an England steeped in the past and racially exclusive. Writing over 70 years after Morton, Joe Bennett's Mustn't Grumble. In Search of England and the English retraces Morton's steps and offers a postcolonial deconstruction of the "myths" of England that Morton had so painstakingly created. In the process, Bennett shows that Morton's image of England still pervades society to this present day and warns of the dangers of uncritically adopting national stereotypes put forward by literature as well as the tourism and heritage industry.

Keywords: Englishness; myth; landscape; H.V. Morton; Joe Bennett.

The political fluidity of national borders in recent decades - the fall of the Berlin Wall and the reunification of Germany; the breakup of Yugoslavia, the recent unrest about borders and identity in Ukraine; even the Scottish Independence debate with the threatened breakup of "Britain" - belies the relative stability that "imagined" nations hold in their people's consciousness, and to which for centuries literature and culture have contributed vitally by formulating and cementing notions of patriotism, belonging, and national identity. While a discussion of shifting European borders might not obviously include a discussion of "Englishness", this article is about the 
attempts by two Englishmen, over 70 years apart, to map what "England" and "Englishness" means to them, and what delimits it from the rest of Europe. The contemporary travel writer Joe Bennett provides some critical, postcolonial distance to the earlier and quasi-mythological commentary on England by H.V. Morton. As Stephen Yeo points out, "behind the myths of 'Englishness' lies the reality of Imperialist Britain" (310). Englishness, both past and present, cannot and should not therefore be discussed without due consideration of the imperial past and its effects on English national identity up to the present day. This article assesses the creation of a specific Englishness and the invention of specific English myths. In the mid 1920s H. V. Morton travelled the length and breadth of England in the aftermath of the First World War, when England was still the centre of a vast Empire but was undergoing important social, political and cultural changes. Since its publication, his In Search of England has contributed towards the creation of a quasi-mythical Englishness that still has considerable currency in contemporary cultural politics. In particular, this article will argue that Morton's focus on rural England, and his refusal to even consider the heavily industrialised region between Birmingham and Liverpool, helped establish and, importantly, perpetuate, the myth of England as a pre-lapsarian, rural country, famed for its rolling hills and pastures green. This image of an unspoilt, safe, peaceful England stood in stark opposition to the modern, urbanised centres of England that, even in the 1920s, were seeing a considerable influx of non-English migrants; it was rooted in an ideology that was strictly white and Anglo-Saxon, and was built on the principle of exclusion of all those that were "Other".

Homi Bhabha refers to "landscape as the inscape of national identity" (1990b 295), palimpsestically created through past histories that need to be recognised and understood in order to forge a sense of community and, importantly, unity. As 
Stephen Daniels and Denis Cosgrove point out, "landscape is a cultural image" - but it is one that can only be "deciphered by those cognisant of the culture as a whole in which they were produced" (1-2). This makes it exclusive, accessible in its full meaning only for the initiated "few" (metaphorically speaking) belonging to this particular culture. For Bhabha, nations can thus be written, can be created through repetitive narration: "the very act of the narrative performance interpellates a growing circle of national subjects" (1990b 297). Literature thus assumes a mythopoeic function: it helps create and perpetuate myths old and new alike and so contributes to cementing a notion of community, belonging and (national) identity. It is only these initiated national subjects who understand the landscape around them, who can read the "signs" hidden in it. Crucially, Bhabha points out that "the political unity of the nation consists in a continual displacement of its irredeemably plural modern space ... into a signifying space that is archaic and mythical". For Bhabha, such "narratives and discourses ... signify a sense of "nationness"" by repeatedly praising "the heimlich pleasures of the hearth" while simultaneously scaremongering about the "unheimlich terror of the space or race of the Other" (1990a 2). By "turning Territory into Tradition" Bhabha concludes that "the People [are turned] into One" (1990b 300). The created myth of rurual England was just such a "territory" turned into "tradition", and as such it was directly opposed to the country's increasing dependence (especially in economic terms) on the Empire. Problematically, this mythical, pastoral England is one that is still celebrated today; one only has to think of calendars featuring picturesquely thatched cottages clustered around village greens; marketing campaigns by the tourist board; or period drama with, traditionally, rural and upper-(middle-) class settings. The heritage industry in particular thrives on presentations of England as a country idyll unspoilt by "modernity". This image of an England of rolling hills, 
empty but for flocks of contented sheep, is the one that millions of people all over the world, fed on a diet of classical literature and TV adaptations, still subscribe to; the "real", twenty-first century England, a modern, multi-cultural nation with buzzing urban centres where the majority of the population actually live and where Chicken Tikka Masala has long since replaced Fish'n Chips as the most popular "English" food, is excluded. While this might seem to be, at best, an example of harmless nostalgia or an instance of cynical, profit-driven marketing, it is a politically motivated manipulation of the image of England that is highly exclusive and that needs to be challenged.

Joe Bennett, the second author under discussion here, tries to do precisely that. Another World War, loss of Empire, a Cold War and several other world crises after In Search of England, his Mustn't Grumble. In Search of England and the English of 2006 retraces the footsteps of Morton in his quest for twenty-first-century England and contemporary Englishness. Bennett, who has spent the majority of his adult life living away from England, in particular in New Zealand, views England from a postcolonial distance and is sarcastically and critically aware of the mythical creations in Morton's work. Nevertheless, he has to realize just how stubbornly they have survived and also, importantly, how much his own conceptions of England have been clouded by them. Instead of feeling the shared sense of "belonging", of the one communal and unifying Englishness that Morton experienced in a moment of epiphany at the end of his journey, the end of Bennett's journey still sees him confused. Englishness, he realises, is almost impossible to pin down in narrow definitions. But Bennett, unlike Morton, does not set out to find definite answers. This makes him part of a movement critically assessing mythical notions of Englishness on the eve of an ever increasing British devolution, and trying to develop alternative 
versions of not one but many Englishnesses more in keeping with a modern, forwardlooking nation. ${ }^{\mathrm{i}}$

Both In Search of England and Mustn't Grumble are travelogues, their authors travelling their own country of birth in order to find out about their roots and the country as a whole. As Justin D. Edwards and Rune Graulund point out, in the field of postcolonial studies, travel writing has often been demonized. Critics have, at times, aligned travel narratives with other textual practices associated with colonial expansion - mapping, botany, ethnography, journalism and so on - to suggest that travel writing disseminated discourses of difference that were then used to justify colonial projects. (1)

According to those critics, travel writing has been used to highlight the "exotic" (read: dangerous) Otherness of places far from the "Motherland". Morton's In Search of England can be seen as a perfect example of such cultural mapping and a true product of its time: crucially, though, it does not "exoticise" far-flung places but, instead, mythically maps the "Motherland" which he constructs as the unquestioned "norm", the only place to find solace and achieve a sense of belonging and identity. As John Baxendale and Chris Pawling point out, Morton (and other inter-war travellers around England, such as, for example, Arthur Mee) "are constructing identity, not revealing it" (15). This means that they are not merely chronicling what they find but rather actively develop and build $a$ version of England that suits them - and the prevalent political mood of the time. Instead of emphasising the subjective nature of this impression of England it is presented as a universally accepted one. As such, In Search of England has achieved a prescriptive status that has had repercussions above and beyond its mere existence as a much-read book. Bennett, by contrast, writing 70 
years after Morton, comes from a politically more inclusive background where multiculturalism and hybridity have become an (at least theoretical) reality - and with beneficial historical hindsight: he uses his travelogue not simply to affirm but to question his own identity and challenge the perceptions about the country of his birth. His travelogue, then, falls into a new category of travel writing, identified by Inderpal Grewal as "evading ... consolidations [of stable unitary identities of nation]" (3). Mustn't Grumble is a postcolonial counter-travelogue of the "Motherland" that challenges the Mortonian myth of England as the centre of the world. Morton presents unquestioned "authenticity". Bennett, by contrast, challenges and queries in his search for a hybrid, contemporary and modern England underneath the plethora of mythical images that have stubbornly clung to the idea of England up to the present day.

Every country has its own myths - stories and images that have been passed down through the generations and that are known and understood by its people. There are particularly many myths associated with Englishness: the myth of King Arthur and his Knights of the Round Table, for example; the idea that Englishmen and women have permanently stiff upper lips and a cup of tea always at the ready. There is evidently only a fine line dividing "myth" from "legend" on the one hand, and "cliché" from "stereotype" on the other. Darko Suvin explains that, "in ethnology, 'myth' is indistinguishable from 'legend' or 'folklore"' but that for cultural historians "myth" has come to denote images that are commonly recognised and understood (147). Timothy Brennan similarly asserts the various meanings of "myth": "myth as distortion or lie; myth as mythology, legend, or oral tradition; myth as literature per $s e$; myth as shibboleth - all of these meanings are present at different times in the writing of modern political culture" (44). In particular, myths are and have been used 
as vital components in the creation of national identity: images and stories that are commonly recognised and understood form an important common ground for the "community" of any given nation. As such, however, "myths" can be - and have been - turned into political tools. As with any image or story, they can be adopted, but, crucially, adapted, too: changed and manipulated according to different but generally politically motivated agendas. And therein lies their danger: for what is recognised so popularly, and so easily, is also, often, accepted unquestioningly. This is particularly problematic when myths are actively created in order to further or invent a new direction in national identity in response to political or social events. Michael Bell has pointed out that 'over the latter part of the $\left[20^{\text {th }}\right]$ century... 'myth' has given way to 'ideology'..." (226) and the use of "the green and pleasant land", a quasi-mythical English landscape, in the construction of English national identity is a particularly pertinent example. Alun Howkins claims that, "Since 1861 England has been an urban and industrial nation... Yet the ideology of England and Englishness is to a remarkable degree rural. Most importantly, a large part of the English ideal is rural" (62). He convincingly outlines the development of the myth of rural England between the 1880s and the late 1920s. This adoption of a specifically Southern English landscape as a place of true Englishness, the home of peace, tranquillity, harmony and tradition, came, as Howkins shows, as a conscious and deliberate response to social, economic and political developments of the time: the decline of manufacture in the north of the country as a result of increasing competition from other European nations but also the United States; urban sprawl with overcrowding of inner-cities, depopulation of the countryside, and mushrooming suburbs; and the increasing orientation towards imperial expansion with its associated imperial discourse and migration that seemed to grow into a threat to "true" Englishness. Joseph Conrad's 
novel The Secret Agent of 1907, for example, illustrates the growing xenophobia, paranoia and fear of the "foreign other" prevalent in London in the early twentieth century. Campaigners called for the "maintenance of a healthy, vigorous and moral race" (Lord Milner, 1911, quoted in Howkins 67) that should return to its roots in the countryside. The use of the word "race" in connection with a developing landscape ideology is clearly particularly problematic, as Ina Habermann has shown, linked as it is to a "blood-and-soil mentality" soon to be abused by the National Socialists in Germany (15ff). This rallying cry of "Back to the Land" was one that campaigners of all political colours shared, and the countryside was thus elevated to mythical status as the home of true Englishness: Anglo-Saxon; white; and grounded in a racially exclusive discourse of the soil. As Howkins outlines, "in contrast to the towns, and London in particular, the country and country people were seen as the essence of England, uncontaminated by racial degeneration and the false values of urban life" (69). During the First World War, the Southern English countryside was held up as "worth fighting for" (see Berberich 2010) and special publications, such as Ernest Rhys's The Old Country. A Book of Love and Praise of England (1917) were handed out to the soldiers fighting in the trenches to remind them what precisely they were sacrificing their lives for. The War Poets considerably contributed to cementing this notion of rural England as a place of solace and sustenance in times of crisis. PostWorld-War-One, Stanley Earl Baldwin philosophised that "to me, England is the country and the country is England" (6-7) - landscape and nation were by then clearly conflated, the mythical landscape pressed into the service of a dubious political ideology. John Short confirms that "in England the two meanings of country, as countryside and nation, are collapsed into one another; the essence of England is popularly thought to be the green countryside" (in Halfacree 143). Ivan Strenski refers 
to Bronislaw Malinowski's approach to myth whereby "myths sing the praises of 'the glorious past' and 'enliven' the natural landscape by assigning landmark significance to otherwise meaningless places" (in Habermann 14). In the span of just a few decades, the Southern English countryside had not only become mythologised but, in consequence, highly politicised. It had lost its very "real" meaning as a site of agricultural production and had, in the language of Barthes (see 131ff), become appropriated by society and been turned into a "signifier", a mere object, albeit one with a "signified" (an associated concept, in this case images of purity, harmony, tranquillity) attached to it. The "sign", the combination of signifier and signified, is laden with a specific meaning - and, in this case, became the "new" myth of the Southern English landscape as the spiritual home of true Englishmen and -women. Englishness is thus not a natural concept, grown organically over centuries, but, instead, an artificial and relatively recent concept, devised and constructed in an attempt to demarcate the boundaries between England and all "Others".

This notion of rural England was one taken up, expanded, developed and, consequently, perpetuated by many early twentieth-century writers, and not only travel writers. Even celebrated Modernists such as E.M. Forster waxed lyrical about the idyllic English countryside that was under constant onslaught from urban sprawl: "Nature withdrew", Forster laments, and he concludes that "If one wanted to show a foreigner England the wisest course would be to take him to the final section of the Purbeck Hills" or "the glorious downs of central England" (115; 170). As in the prevalent political ideology of the time, Howards End depicts urban centres, in particular London, as places that are culturally stimulating but that "cannot sustain" (155). Howards End deals with the main concerns of its time, moving, as it does, 
between the pastoral idyll of the house Howards End, the fast-changing metropolis London, and the imperial space represented by the Wilcoxes' business. Admittedly, it does not condemn urban or imperial spaces; yet it ultimately holds up pastoral England as the one place where its characters can find true belonging.

The "return to the country" movement of the late nineteenth and early twentieth century came at a time of social upheaval and the irrational and unfounded fear of the growing Empire and its influence on English daily life; by elevating the countryside to its new mythical status, politicians, campaigners, artists and writers alike sought to establish a sense of stability with the aim of drawing the English closer together and creating a barrier against incoming "Others". And in the process, as Howkins puts it, "the cultural history of England had to be rewritten" (69).

In Search of England starts with a highly Orientalist discourse of "us" versus "them", of "home" versus "abroad": believing himself to be dying of spinal meningitis, Morton allegedly climbs a hill in Jerusalem, turns in the direction of England - and, in a prayer-like moment, gives in to a powerful "wave of home-sickness" (13). The word "allegedly" is chosen consciously here, as the image Morton creates provides him with a useful unheimlich setting against which he can contrast "homely" England. Surrounded by the "inhospitable mountains" of a country that is decidedly not England, he vows that "if ever I saw Dover Cliffs again I would never leave them" (13). ${ }^{\text {ii }}$ Morton thus immediately juxtaposes two very different spaces: Palestine, barren, inhospitable, alien, a place that for him almost comes to symbolise death; and England, beckoning from far away with her mythologised white cliffs and green hills, a place offering nothing but peace, and hope. The image of England that Morton conjures up on the Jerusalem hill is one of 
a village street at dusk with a smell of wood smoke lying in the still air, and here and there, little red blinds shining in the dusk under the thatch. I remembered how the church bells ring at home... and [how] you hear the slow jingle of a team coming home from the fields. (13-14)

Remarkably, Morton, who lived in London for much of his professional life, does not conjure up his own hometown. He claims that "this vision of mine is a common one to exiles all over the world: we think of home, we long for home, but we see something greater - we see England" (14; emphasis in the original). For Morton, it is thus "the village that symbolizes England" (14): the mythologised countryside that is synonymous with the nation as a whole.

The opening chapter of In Search of England sets the tone for the overall book. The words "England" and "English" are repeated countless times, a comforting mantra, the two words that sustain Morton through illness and despair in Palestine: "I would go home in search of England. I would go through the lanes of England and the little thatched villages of England, and I would lean over English bridges and lie on English grass, watching an English sky" (14). The England he envisages - and which he comes back home to explore - is one characterised by the colour green, traditionally the colour denoting harmony, growth, and hope: "I sped on into a green tunnel of a lane, with England before me; and the keen air was like wine to me, and the green of the young leaves was like music" (18). After the barrenness of the Palestinian desert, England is invigorating for Morton. The trauma and illness associated with the First World War and his time in Palestine disappears. Like the "young leaves" he conjures up, Morton, too, seems to have a new lease of life.

But although Morton's journey starts with the image of him looking ahead into the hopeful and beckoning "green tunnel" of England, he spends the majority of his 
journey not positively looking ahead into the future but, instead, wistfully looking back at the past. He professes himself that he is trying "to look back into ... time" (25). In Winchester, for instance, he stresses the city's status as England's first capital where "the princes of this city emerged as the kings of Wessex ... and later became the kings of England", a city "truly [at] the very heart of England until Westminster Hall and the Abbey gathered round them the royal city of a new England" (25). But Morton is not interested in this "new" England. His England refers solely to the past, to folklore, to tradition, and it is this backwards orientation and its focus on a very few selected places and historical events that makes In Search of England so problematic. In Bucklebury, for example, he visits the "last bowl-turner in England" (19ff) who not only lives in an idyllic village setting but whose very cottage was, in fact, "an Anglo-Saxon workshop" (21), steeped in centuries of a quintessential English past that precedes the last and most significant "foreign" invasion of the country through the Normans. In a time when the country is, as Morton sees it, once again threatened by a new "invasion" of sorts, that of foreign individuals coming to live and work in England, people like William Lailey, the bowl turner, who "turns bowls exactly as they did in the days of Alfred the Great" (20), seem to be the true carriers of English culture: steeped in tradition, unaffected by modernity, uninterested in the trappings of modern lifestyles or little luxuries. As Alun Howkins points out, in the construction of a new rural English culture in the early twentieth century, "culture was to be found in the arts of the countryside and its people" (72). Morton, having found the one remaining bowl maker in the country, not only immortalises him as a true representative of English tradition and English culture but, in the process, romanticises Lailey's lifestyle. Rather than trying to engage with contemporary Englishness, Morton consciously constructs a mythologised Englishness that might be 
harmonious but that is also doomed to fade: Lailey is, indeed, the last of the bowl turners, and the tradition will end with him.

There are some very few glimpses of irony in Morton's account, moments when he realises that the idealised past has been turned into consumerism. In particular when visiting Stratford-on-Avon he realises that this revered site has been transformed into a haven for American day-trippers (254ff). However, overall Morton turns a blind eye and prefers to focus on the past, emphasising buildings, trades and sites that have been there since time immemorial and that he sees as having survived, unaffected by modernity. He dwells on the mythical power that Glastonbury still holds (134ff); on the mediaeval beauty of Wells (140); on a church in the small town of Bradford-on-Avon that still stands unchanged "as it was 1,000 years ago" (154); he conjures up mediaeval romances (173); and praises ancient skills such as flint chipping, practiced in Suffolk since the Stone Age (250). And above all else, he always conjures up the timeless beauty of the countryside - "the green Worcester valleys; the neat, pretty Hereford orchards; the trim Gloucester fields" (172), "these ... lanes, deep and banked; these mighty trees; these small, arched bridges over small streams" (254) - untouched, peaceful, "deep" England, the countryside he remembers from his childhood and which he wants to preserve.

Morton's In Search of England is thus, as Haberman says, an example of "performative" travel (64): he performs to a perceived audience, those "in the know" already, who will understand his allusions and who share his sentiments. According to David Matless, Morton's "search for England is based on social and aesthetic distinctions concerning how to look and who could see the country" (66) and this is problematic for a variety of reasons. First and foremost, it makes his search for England exclusive. Not everybody can search for and, crucially, find this "real" 
England, in particular as the England he presents is in itself exclusive in that Morton only presents a highly selective picture. And secondly it leads to a careful staging of the country, with Morton only showing what he wants to show, what he wants to see and what he thinks his readership ought to see. His England thus becomes "a highly theatrical place" (Matless 66-67) that presents as real and authentic something that is not. As Matless points out, "sites become archetypes, and if they are not archetypes they are not proper sites" (67). Nowhere does this become more obvious than in the last few paragraphs of the text that see him walking across a "churchyard where the green stones nodded together", and where he "took up a handful of earth and felt it crumble and run through my fingers, thinking that as long as one English field lies against another there is something left in the world for a man to love. 'Well,' smiled the vicar, as he walked towards me between the yew trees, 'that, I am afraid, is all we have.' 'You have England,' I said" (Morton 276-7). With those last few lines of the book Morton - following a long tradition - links himself irrevocably to the land, holding England, literally, in the palm of his hand. He has come full circle, from the cold mountains overlooking Jerusalem in a foreign land, to finding Jerusalem in England's green and pleasant land.

Joe Bennett, by contrast, tackles the mythical England Morton presents from the outset of his book, and his journey could consequently be labeled a "de-mythyfying" one. Planning his journey in New Zealand and re-reading In Search of England he realises that "[Morton's] purpose, openly expressed, was to find the real England, the core of Englishness. He duly found it. It was an England of rural stolidity, drenched in the past. It seemed unruffled by the recent world war" (2). Morton, Bennett understands, only presented the highly selective England he wanted to perpetuate - 
and succeeded in that as "his picture of England has proved remarkably durable. It remains in the collective mind..." (11). By contrast, Bennett's encounters with England acquaint him with rubbish by the wayside; uncaring traffic roaring past his raised thumb; concrete shopping malls and dying city centres; unfriendly landlords of inadequate B\&Bs. He openly tackles the myths that Morton had been at great pains to either emphasize or create in the first place - and the first one he starts with is, appropriately that of William Lailey, the last bowl-turner. Fingering one of Lailey's actual bowls Bennett is initially taken in by Morton's story. But in a small museum in Newbury he finds out that "the first two generations of Laileys made bowls as a side line ... but after 1927, when a romantic description of their work was published, George [Morton had got the bowl turner's first name wrong] was able to earn his livelihood by turning bowls" (31). Morton's account, Bennett realizes, "must have led hundreds of people to do as I did yesterday, making the pilgrimage to Bucklebury Common in search of an older England" (31). He concludes that "Effectively Morton made Lailey into a saint of sorts, his hut a shrine. And saintly George, it seems, was happy to sell every pilgrim a hand-turned wooden relic" (31). The created myth of the bowl turner who works according to ancient traditions has contributed to the conscious rewriting of the country's history (see Howkins 69) - but has also had a profitable commercial side effect for its central character that thus clearly links myth and national identity to commerce.

Bennett continues to deconstruct Morton's myths one by one. Combe Gallows is unmasked since it "never hanged a man. The original did, but it has since rotted and been replaced, not once, but several times" (46); King Arthur's Round Table in Winchester Great Hall is exposed as a "Tudor fake" (55); the moving gravestone of "Thomas Thatcher a Grenadier in the North Regt. Of Hants Militia who died of a 
violent fever contracted by drinking Small Beer when hot the $12^{\text {th }}$ of May 1764. Aged 26 years" (55) in Winchester Cathedral Close is revealed to be one of several replacements of the original stone serving to maintain the myth. Bennett laments that "The reason this stone has been replaced is that time has transmuted this young man's death into something delicious" (55). ${ }^{\text {iii }}$ At Land's End he similarly complains that the celebrated Undercover Attraction area is more than repellent. ... it [is] simultaneously absurd, hateful and terminally saddening. It's a distillation of pap, a Disneyland of verbal dishonesty. "Heroism, skulduggery and adventure" mean sanitized glorifications of fighting and illegality. "Monsters" is a bald lie. "Pirates" were thieves. "Smugglers" were tax-dodgers. "Wreckers" were vultures. "Arthur and the Age of the Knights" were more or less mythical. (119)

The England Bennett encounters is thus not one of organically grown traditions but one that merely upholds the idea of the traditional by selling copies and replicas to the public. He concludes, early on in his journey, that "It's the tourist mantra around the world but especially in England. Old is good and modern is bad. Today is an unenchanting mess. Yesterday was a mess too, once, with its poverty, suffering and violence, but time has composted it into sweet-smelling stories" (31). History appears to have been divorced from its factual status and has, instead, been pressed into the service of entertainment. Bennett, who initially sets out to follow in Morton's footsteps, realises soon that "if I follow Morton too closely I shall often find myself at a loss" (67) because Morton's prescriptive account has clouded his own picture of England as much as his childhood reading of Enid Blyton: "images [of England] that prevailed, that formed my template of ideal and essential Englishness, an image that endures however much experience may contradict it" (23). The past, Bennett 
understands, has been (ab)used to construct an image of England that almost entirely excludes the present. It has been adapted, distilled and manipulated in a way that excludes potentially contradictory or unpleasing aspects:

The past you can grasp. It has been moulded into stories... You can hold these things in your hand like a box of eggs, all neatly parcelled and recognizable. But the present is smashed egg. It drips between your fingers. It's a mere mess.

And because the past is presented as more palatable, the present is being ignored. Wherever Bennett goes in England, Morton has gone before him, or another book, fictional or otherwise, has presented a formative account. The travel writer Paul Theroux has famously stated that "There were no blank spaces on the map of Great Britain, the best-known, most fastidiously mapped and most widely trampled piece of geography on earth" (Theroux 15). For Bennett, it is vital he finds "his own" England, one without prescriptive images already inserted into his consciousness. But he finds that, wherever he goes, places are only too happy to actively "sell" themselves through their past (regardless of how tangential a link this can be), and not their future potential. This results in a "burden of yesterdays" (Bennett 89) that prevents him, and ultimately all of us, from forming our own opinions and experiencing the country with fresh eyes. He explains that places such as Land's End, Hardy's house, Betjeman's grave or Laurie Lee's village only have the significance that we have artificially "invested in them" (259). Habermann writes that "to speak about Englishness is always to tell stories about collective identity, and thus in a way to engage in a process of mythmaking" (29); engaging with English national identity, she suggests, thus results in perpetuating myths. But the trick is to liberate ourselves from prescribed notions, ideas and myths. Just like Morton, Bennett also experiences 
a moment of epiphany during his journey. But his comes in a small pub in Princetown, on Dartmoor, where a brass plaque on the wall simply reads "In 1832 ... on this spot nothing happened" (Bennett 141). For Bennett, this place is unique in that it does not sell itself through its past, in that it leaves itself the space to find individual and multiple meanings in the present. And for him, it thus becomes a place where he does not feel obliged to ponder historical events, or the people who have been there before him, but where he simply has "a lovely evening". He concludes that "in short, on 24 April 2005 on this spot nothing happened" (142). The historically unencumbered pub thus becomes an affective space for him, an ordinary, everyday space that he can well and truly invest with his own, personal meaning.

Predictably, Bennett concludes with Morton's moment of epiphany, the famous moment of soil-in-hand in the country churchyard. But Bennett challenges this most potent of Morton's myths, that of the soil of England conveying a sense of belonging, of the one, quintessential Englishness, by claiming that "Morton's archetypal English village comes with no name. I suspect that he embellished it beyond recognition, or else that he simply made it up" (276). This is Bennett's most decisive de(con)struction of Morton's myths as it ultimately reveals In Search of England as a piece of fiction, a work about invented traditions and an imagined and exclusive community of Englishness - albeit a fiction that has sustained its powerful lure over the decades. What Morton had depicted as authentically English (the historical sites, the traditional occupations, the unchanged landscapes) Bennett shows up to be fakes. Gareth Griffiths writes that "claims to an 'authentic' voice ... may be a form of overwriting the complex actuality of difference equal but opposite to the more overt writing out of that voice in earlier oppressive discourses" (70). Morton assumed a 
voice of authority in his account; occasionally, he allows others to speak, but only after assuring his readers that those people are "authentic": "here... is the typical old man for whom I have been looking since I struck Exmoor" (Morton 127). As with the bowl turner, he converts the old man on Exmoor to an icon of traditional Englishness, as a, in Griffiths' words, "a mythologized and fetishized sign of the 'authentic"” (71). But despite his awareness of this, Bennett's account of his journey around England ends on an inconclusive note. He has moved from following in the footsteps of Morton to desperately trying to get out of Morton's footsteps in order to form his own opinions. He acknowledges that "in the interlude between Morton's birth and mine, something snapped" (Bennett 94) that affects his own sense of patriotic fervour, pride, and national identity. Bennett acknowledges decolonisation; he talks about and celebrates contemporary, multi-cultural British society that features praying Muslim bus drivers - "I bet Morton didn't see that in Winchester" (63) - or cheerful Mauritian waitresses (267). But although he challenges Morton's myths, he does not come up with a real alternative. But maybe that is precisely the point. Bennett's text needs to be read as an antidote to libraries full of prescriptive writing about England that have cemented the image of a country steeped in the past and out of step with contemporary society. As Andrea Binelli has remarked in a different context, hopes are likely to come true only in a pluralist, a-hierarchical society, in which hybridity ... will debunk the fallacy of those pretensions to authenticity that are based on principles of exclusiveness. Mythology would then lose its social function to exclude and could acquire a new strength by disclosing itself to difference.... . (166).

The images we each and everyone have of our European surroundings are steeped in the past, in tradition, in myth - and those images have, for centuries, been changed, 
adopted, adapted and manipulated. Myths are entertaining stories. But that is all they should be. Bennett reveals to us the need to actively create our own imaginary topographies in contemporary England and, by extension, in contemporary Europe that do not claim to be anything but subjective and individual.

\section{Works Cited}

Barthes, Roland. Mythologies. Transl. Annette Lavers and Siân Reynolds. London: Vintage Books, [1972] 2009.

Baxendale, John \& Chris Pawling. Narrating the Thirties. Basingstoke: Palgrave Macmillan, 1995.

Bennett, Joe. Mustn't Grumble. In Search of England and the English. London:

Simon and Schuster / Pocket Books, 2007 (2006).

Berberich, Christine. “'Isn’t this worth fighting for?' World War I and the Uses of the Pastoral Tradition". Bodies-at-War: Conflict, Nationhood and Corporeality in

Modern Literature. Ed. Petra Rau. Basingstoke: Palgrave Macmillan, 2010. 26 — 45.

Bhabha, Homi K. "Introduction: Narrating the Nation". Nation and Narration. Ed.

Homi K. Bhabha. London: Routledge, 1990a. 1—7.

Bhabha, Homi K. "DissemiNation: Time, Narrative, and the Margins of the Modern

Nation". Nation and Narration. Ed. Homi K. Bhabha. London: Routledge, 1990b.

$291-322$.

Binelli, Andrea. "Places of Myth in Ireland". Myths of Europe. Eds Richard

Littlejohns \& Sara Soncini. Amsterdam: Rodopi, 2007. 155-69.

Brennan, Timothy. "The National Longing for Form". Nation and Narration. Ed.

Homi K. Bhabha. London: Routledge, 1990. 44-70. 
Daniels, Stephen \& Denis Cosgrove. "Introduction: Iconography and Landscape".

The Iconography of Landscape. Essays on the Symbolic Representation, Design and

Use of Past Environments. Eds Denis Cosgrove \& Stephen Daniels. Cambridge:

Cambridge University Press, 1988. 1-10.

Edwards, Justin D. \& Rune Graulund. "Introduction: Reading Postcolonial Travel

Writing”. Post-Colonial Travel Writing. Critical Explorations. Eds Justin D. Edwards

\& Rune Graulund. Basingstoke: Palgrave, 2011. 1-16.

Forster, E.M. Howards End. London: Penguin, [1910] 1983.

Grewal, Inderpal. Home and Harem: Nation, Gender, Empire, and the Culture of

Travel. Durham, NC: Duke University Press, 1996.

Griffiths, Gareth. "The Myth of Authenticity. Representation, Discourse and Social Practice". De-Scribing Empire. Post-Colonialism and Textuality. Eds Chris Tiffin \& Alan Lawson. Basingstoke: Routledge, 1994. 70—85.

Habermann, Ina. Myth, Memory and the Middlebrow. Priestly, du Maurier and the Symbolic Form of Englishness. London: Palgrave Macmillan, 2010.

Halfacree, Keith. "Landscapes of Rurality: Rural Others/Other Rurals”. Studying

Cultural Landscapes. Eds Iain Robertson \& Penny Richards. London: Hodder Arnold, 2003. $141-69$.

Howkins, Alun. “The Discovery of Rural England”. Englishness. Politics and Culture 1880 — 1920. Eds. Robert Colls \& Philip Dodd. London: Croom Helm, 1986. 62—88. Matless, David. Landscape and Englishness. London: Reaktion Books, 1998.

Morton, H. V. In Search of England. London: Penguin Books, 1960 (1927).

Suvin, Darko. "Some Differentiations within the Concept of Myth". Myths of Europe. Eds Richard Littlejohns \& Sara Soncini. Amsterdam: Rodopi, 2007. 147—54.

Theroux, Paul. Kingdom by the Sea. Harmondsworth: Penguin, 1984 (1983). 
Yeo, Stephen. "Socialism, the State, and Some Oppositional Englishness".

Englishness. Politics and Culture 1880-1920. Eds Robert Colls \& Philip Dodd.

Beckenham: Croom Helm, 1986. 308-69.

\footnotetext{
${ }^{\text {i }}$ For a discussion of contemporary notions of different Englands see also Christine Berberich \& Arthur Aughey (eds), These Englands. A Conversation on National Identity (Manchester:

Manchester University Press, 2011).

ii Incidentally, this is a vow Morton broke quite easily as he eventually relocated to South Africa where he rather worryingly lived all too happily under the Apartheid regime.

iii Postcard reproductions of this particular gravestone are readily available in the souvenir shops surrounding Winchester Cathedral.
} 